\title{
Effects of High Temperature and Disinfectants on the Viability of Sarcocystis neurona Sporocysts
}

Author(s): J. P. Dubey, W. J. Saville, C. Sreekumar, S. K. Shen, D. S. Lindsay , H. F. Pena, M. C. Vianna, S. M. Gennari, and S. M. Reed

Source: Journal of Parasitology, 88(6):1252-1254. 2002.

Published By: American Society of Parasitologists

DOI: http://dx.doi.org/10.1645/0022-3395(2002)088[1252:EOHTAD]2.0.CO;2

URL: http://www.bioone.org/doi/full/10.1645/0022-3395\%282002\%29088\%5B1252\%3AEOHTAD $\% 5 \mathrm{D} 2.0 . \mathrm{CO} \% 3 \mathrm{~B} 2$

BioOne (www.bioone.org) is a nonprofit, online aggregation of core research in the biological, ecological, and environmental sciences. BioOne provides a sustainable online platform for over 170 journals and books published by nonprofit societies, associations, museums, institutions, and presses.

Your use of this PDF, the BioOne Web site, and all posted and associated content indicates your acceptance of BioOne's Terms of Use, available at www.bioone.org/page/terms_of_use.

Usage of BioOne content is strictly limited to personal, educational, and non-commercial use. Commercial inquiries or rights and permissions requests should be directed to the individual publisher as copyright holder. 
American Society of Parasitology. J. P. Dubey, W. J. Saville, C. Sreekumar, S. K. Shen, D. S. Lindsay, H. F. Pena, M. C. Vianna, S. M. Gennari, and S. M. Reed (2002). "Effects of High Temperature and Disinfectants on the Viability of Sarcocystis neurona Sporocysts," Journal of Parasitology, Vol. 88, No. 6, pp. 1252-1254. doi: http://dx.doi.org/10.1645/0022-3395(2002)088[1252:EOHTAD]2.0.CO;2

\section{Effects of High Temperature and Disinfectants on the Viability of Sarcocystis neurona Sporocysts}

J. P. Dubey, W. J. Saville*, C. Sreekumar, S. K. Shen, D. S. Lindsay†, H. F. Penał, M. C. Viannał, S. M. Gennarił, and S. M. Reed§, Parasite Biology, Epidemiology and Systematics Laboratory, Building 1001, Animal and Natural Resources Institute, Agricultural Research Service, United States Department of Agriculture, Beltsville, Maryland 20705-2350; *Department of Veterinary Preventive Medicine, College of Veterinary Medicine, The Ohio State University, 1900 Coffey Road, Columbus, Ohio 43210-1092; †Center for Molecular and Infectious Diseases, Department of Biomedical Sciences and Pathobiology, Virginia-Maryland Regional College of Veterinary Medicine, 1410 Prices Fork Road, Virginia-Tech, Virginia 24061-0342; łFaculdade de Medicina Veterinária e Zootecnia da Universidade de São Paulo, Av. Prof. Dr. Orlando marques de paiva, 87, CEP 05508, São Paulo, Brazil; §Department of Large Animal Medicine, College of Veterinary Medicine, The Ohio State University, Columbus, Ohio 43210-1092. e-mail: jdubey@anri.barc.usda.gov

ABSTRACT: The effect of moist heat and several disinfectants on Sarcocystis neurona sporocysts was investigated. Sporocysts (4 million) were suspended in water and heated to $50,55,60,65$, and 70 $\mathrm{C}$ for various times and were then bioassayed in interferon gamma gene knockout (KO) mice. Sporocysts heated to $50 \mathrm{C}$ for $60 \mathrm{~min}$ and $55 \mathrm{C}$ for $5 \mathrm{~min}$ were infective to $\mathrm{KO}$ mice, whereas sporocysts heated to $55 \mathrm{C}$ for $15 \mathrm{~min}$ and $60 \mathrm{C}$ or more for $1 \mathrm{~min}$ were rendered noninfective to mice. Treatment with bleach (10,20, and 100\%), $2 \%$ chlorhexidine, $1 \%$ betadine, $5 \% o$-benzyl-p-chlorophenol, $12.56 \%$ phenol, $6 \%$ benzyl ammonium chloride, and $10 \%$ formalin was not effective in killing sporocysts. Treatment with undiluted ammonium hydroxide (29.5\% ammonia) for $1 \mathrm{hr}$ killed sporocysts, but treatment 
TABLE I. Survival of Sarcocystis neurona sporocysts at 50-70 C exposed for $1-60 \mathrm{~min}$.

\begin{tabular}{cccc}
\hline $\begin{array}{c}\text { Tempera- } \\
\text { ture }(\mathrm{C})\end{array}$ & $\begin{array}{c}\text { Exposure } \\
\text { time (min) }\end{array}$ & $\begin{array}{c}\text { No. of mice positive } \\
\text { for } \begin{array}{c}\text { S. neurona/no. } \\
\text { of mice fed }\end{array}\end{array}$ & $\begin{array}{c}\text { Time to } \\
\text { illness, death }\end{array}$ \\
\hline 50 & 2 & $2 / 2$ & 18,19 \\
& 10 & $2 / 2$ & 19,19 \\
& 30 & $2 / 2$ & 20,20 \\
55 & 60 & $2 / 2$ & 20,20 \\
& 1 & $2 / 2$ & 20,20 \\
& 2 & $2 / 2$ & 35,35 \\
& 5 & $2 / 2$ & \\
60 & 15 & $0 / 2$ & \\
& 30 & $0 / 2$ & \\
65 & 1 & $0 / 4 *$ & \\
& 2 & $0 / 4 *$ & \\
70 & 5 & $0 / 2$ & \\
& 1 & $0 / 4 *$ & \\
& 2 & $0 / 4 *$ & \\
\hline
\end{tabular}

* Repeat experiments.

with a 10 -fold dilution (2.95\% ammonia) for $6 \mathrm{hr}$ did not kill sporocysts. These data indicate that heat treatment is the most effective means of killing $S$. neurona sporocysts in the horse feed or in the environment.

Sarcocystis neurona is the most important cause of a neurologic disease of horses in the Americas (Dubey, Lindsay et al., 2001). Horses become infected with $S$. neurona by ingesting sporocysts excreted in feces of infected opossums (Fenger et al., 1997; Cutler et al., 2001; Saville et al., 2001). Approximately $50 \%$ of the horses in the United States were found to have antibodies to $S$. neurona (Dubey, Lindsay et al., 2001). The high prevalence of antibodies to $S$. neurona indicates widespread exposure of the forage or horse feed to $S$. neurona. Practical methods to kill $S$. neurona in the horse environment are not known. Several studies have reported likely cross-contamination of control horses in experimental settings (Cutler et al., 2001; Saville et al., 2001). The objective of the present study was to test the effects of different high temperatures and of commonly used disinfectants for killing sporocysts.

Sarcocystis neurona sporocysts were obtained from the intestinal homogenate of a laboratory-raised opossum (no. 30) that was fed muscles of an experimentally infected raccoon (Dubey, Saville et al., 2001). The raccoon had been fed $S$. neurona sporocysts 78 days before euthanasia. The opossum intestines were homogenized in water, filtered through a 90- $\mu \mathrm{m}$ metallic sieve, suspended in antibiotic saline, and stored at $4 \mathrm{C}$, as described previously (Dubey, 2000). The sporocysts had been stored at $4 \mathrm{C}$ for 2-3 wk before use in the present study.

There were approximately 8 million sporocysts per milliliter of the sporocyst pool used in this study. The viability of sporocysts was determined by bioassays in interferon gamma gene knockout (KO) mice (Dubey and Lindsay, 1998). For bioassay, $0.5 \mathrm{ml}$ of the sporocyst pool was diluted 10 -fold in saline, and $0.5 \mathrm{ml}$ from each aliquot from the $10^{-3}$ to $10^{-6}$ dilutions was fed to each of the $5 \mathrm{KO}$ mice.

To study the effect of exposure to 50-70 C, heat-sealable plastic pouches were used to contain sporocysts so that they were exposed instantly to the desired temperature (Table I). One half milliliter of sporocyst suspension was dispensed into $10 \times 15 \mathrm{~cm}$ boilable plastic bags (Kapak/Scotchpak, Kapak Corporation, Minneapolis, Minnesota). Each bag was sealed to prevent sporocyst spillage. After stated exposure time, pouches were removed immediately from the water bath to room temperature $(22 \mathrm{C})$ and then bioassayed in $2 \mathrm{KO}$ mice for each treatment. There was immediate cooling after removal from the water bath
TABLE II. Effects of disinfectants on viability of Sarcocystis neurona sporocysts.

\begin{tabular}{|c|c|c|}
\hline $\begin{array}{l}\text { Disinfectant and } \\
\text { concentration }(\%)\end{array}$ & $\begin{array}{c}\text { Total } \\
\text { volume }\end{array}$ & $\begin{array}{c}\text { Infectivity } \\
\text { to KO mice* }\end{array}$ \\
\hline \multicolumn{3}{|c|}{ Bleach (Clorox), $5.25 \%$ sodium hypochlorite } \\
\hline 100 & 20 & $4 / 4$ \\
\hline 20 & 20 & $4 / 4$ \\
\hline 10 & 20 & $4 / 4$ \\
\hline \multicolumn{3}{|c|}{ Wex-cide, $12.56 \%$ phenol } \\
\hline 0.003 & 20 & $4 / 4$ \\
\hline \multicolumn{3}{|c|}{ Novalsan, $2 \%$ chlorhexidine } \\
\hline 24 & 20 & $4 / 4$ \\
\hline \multicolumn{3}{|l|}{ Betadine, $1 \%$ iodine } \\
\hline 100 & 20 & $4 / 4$ \\
\hline \multicolumn{3}{|c|}{ TB plus, 5\% o-benzyl-p-chlorophenol } \\
\hline 0.003 & 15 & $4 / 4$ \\
\hline \multicolumn{3}{|l|}{$\begin{array}{l}\text { NPD, } 6 \% \text { benzyl } \\
\text { ammonium chloride }\end{array}$} \\
\hline $0.007 \%$ & 20 & $4 / 4$ \\
\hline Formalin, $10 \%$ & 20 & $4 / 4$ \\
\hline \multicolumn{3}{|l|}{ Ammonium hydroxide } \\
\hline $100 \%$ & 20 & $0 / 4$ \\
\hline $10 \%$ & 20 & $2 / 4$ \\
\hline Untreated & 20 & $4 / 4$ \\
\hline
\end{tabular}

* Number of mice positive for S. neurona of number of mice fed. Data for 1and 6-hr treatments were pooled.

because the pouches were very thin and the small volume was spread over a large area.

To study the effect of different disinfectants, $0.5 \mathrm{ml}$ of the sporocyst suspension was mixed with 15 or $20 \mathrm{ml}$ of the disinfectant in $50-\mathrm{ml}$ tubes (Table II). The disinfectants used in this study included Clorox ${ }^{\circledR}$ (The Clorox Company, Oakland, California), Novalsan ${ }^{\circledR}$ (Fort Dodge Animal Health, Fort Dodge, Iowa), Betadine ${ }^{\circledR}$ (The Purdue Frederick Co., Stamford, Connecticut), TB plus ${ }^{\circledR}$ (Betco, Toledo, Ohio), Wexcide ${ }^{\circledR}$ (Wexford Labs, Inc., Kirkwood, Missouri), NPD ${ }^{\circledR}$ (Covatec/Calgon Vestal Lab., Inc., St. Louis, Missouri), ammonium hydroxide (Sigma, St. louis, Missouri), and $10 \%$ formalin. After 1 or $6 \mathrm{hr}$ of incubation at room temperature, the treated sporocysts were mixed well with $25 \mathrm{ml}$ of water and centrifuged at 2,000 rpm $(1,200 \mathrm{~g})$ for $10 \mathrm{~min}$. After discarding the supernatant, the sediment was mixed with water and centrifuged, and the process was repeated at least 3 times to remove the disinfectants. After a final wash, the materials were fed to $2 \mathrm{KO}$ mice.

The KO mice were examined for $S$. neurona infection. Mice that became ill were killed and their cerebellums examined microscopically for $S$. neurona schizonts and merozoites; the cerebellum is the most heavily parasitized with $S$. neurona in mice examined 25 days after feeding sporocysts (DAFS) (Dubey, 2001). The survivors were bled and killed 2 mo after feeding sporocysts; their sera were tested for antibodies to $S$. neurona in the agglutination test (Lindsay and Dubey, 2001), and their brains were examined immunohistochemically (Dubey and Hamir, 2000). Mice were considered infected when $S$. neurona was demonstrated in their tissues. Mice were considered uninfected when antibodies to $S$. neurona and $S$. neurona parasites were not demonstrable.

The mice fed with sporocysts heated to 50 or $55 \mathrm{C}$ for indicated times developed neurologic signs, and $S$. neurona was demonstrable in their brains (Table I). All mice fed sporocysts heated to $55 \mathrm{C}$ for 15 $\min$ and $60 \mathrm{C}$ for $1 \mathrm{~min}$ or more remained healthy with no demonstrable $S$. neurona stage or antibody. All control mice fed with untreated sporocysts developed neurologic signs and were killed 21-28 DAFS; $S$. neurona was found in the brains of all infected mice. These data indi- 
TABLE III. Infectivity of untreated Sarcocystis neurona sporocysts to KO mice.

\begin{tabular}{ccl}
\hline $\begin{array}{c}\text { Dilution of } \\
\text { inoculum }\end{array}$ & $\begin{array}{c}\text { No. of } \\
\text { mice fed }\end{array}$ & $\begin{array}{l}\text { Day of death } \\
\text { or euthanasia }\end{array}$ \\
\hline $10^{-3}$ & 5 & $30,30,30,31,31$ \\
$10^{-4}$ & 5 & $23,25,28,28,31$ \\
$10^{-5}$ & 5 & $23,31,36, \mathrm{~S}, \mathrm{~S} *$ \\
$10^{-6}$ & 5 & $39, \mathrm{~S}, \mathrm{~S}, \mathrm{~S}, \mathrm{~S}$ \\
\hline
\end{tabular}

$* \mathrm{~S}=$ Survived, no antibody, no parasites.

cate that heating horse feed to $60 \mathrm{C}$ should kill $S$. neurona sporocysts and steaming the contaminated environment (e.g., horse barn) should be effective in killing $S$. neurona sporocysts.

None of the disinfectants tried was effective in killing S. neurona sporocysts, except ammonia (Table II); the mice died of neurologic $S$. neurona infection. The concentrations selected were those advised on the product-label. Exposure to concentrated ammonia killed sporocysts, but diluted ammonia was not effective in killing all sporocysts (Table II)

All 10 mice fed with $10^{-3}$ and $10^{-4}$ dilutions, 3 out of 5 fed with the $10^{-5}$ dilution, and 1 of 5 mice fed with the $10^{-6}$ dilution died of $S$. neurona infection, indicating that there were at least 100,000 viable sporocysts used for each treatment (Table III).

Little is known of the pathogenesis of $S$. neurona infection in horses. All attempts to fulfill Koch's postulates in horses have been unsuccessful. Horses fed with $S$. neurona sporocysts developed mild or moderate neurologic signs, sometimes associated with microscopic lesions but without demonstrable organisms. There are many other difficulties in attempting to induce $S$. neurona infection in horses. First, it is difficult to locate $S$. neurona-negative horses. Second, some of the sporocysts fed to horses pass unexcysted in feces; thus, they are potentially infective to control horses (Cutler et al., 2001; Saville et al., 2001). Results of the present study indicate that to prevent tracking of sporocysts between barns or stalls, it is necessary to change boots or use disposable boot covers because the common practice of using disinfectant footbaths to prevent cross-contamination will not kill sporocysts. In addition, steam cleaning of equine facilities will likely be useful to kill the sporocysts in between animal use.

\section{LITERATURE CITED}

Cutler, T. J., R. J. MacKay, P. E. Ginn, K. Gillis, S. M. Tanhauser, E. V. LeRay, J. B. Dame, And E. C. Greiner. 2001. Immunoconversion against Sarcocystis neurona in normal and dexamethasonetreated horses challenged with $S$. neurona sporocysts. Veterinary Parasitology 95: 197-210.

DubeY, J. P. 2000. Prevalence of Sarcocystis species sporocysts in wild caught opossums (Didelphis virginiana). Journal of Parasitology 86: $705-710$.

2001. Migration and development of Sarcocystis neurona in tissues of interferon gamma knockout mice fed sporocysts from a naturally infected opossums. Veterinary Parasitology 95: 341-351.

- AND A. N. HAMIR. 2000. Immunohistochemical confirmation of Sarcocystis neurona infections in raccoons, mink, cat, skunk and pony. Journal of Parasitology 86: 1150-1152.

, AND D. S. LINDSAY. 1998. Isolation in immunodeficient mice of Sarcocystis neurona from opossum (Didelphis virginiana) faeces, and its differentiation from Sarcocystis falcatula. International Journal for Parasitology 28: 1823-1828.

, D. S. Lindsay, W. J. A. Saville, S. M. Reed, D. E. GranSTROM, AND C. A. SpeER. 2001. A review of Sarcocystis neurona and equine protozoal myeloencephalitis (EPM). Veterinary Parasitology 95: 89-131.

, W. J. A. Saville, J. F. Stanek, D. S. Lindsay, B. M. Rosenthal, M. J. Oglesbee, A. C. Rosypal, C. J. Nuoku, R. W. Stich, O. C. H. Kwok, S. K. Shen, A. N. Hamir, And S. M. Reed. 2001. Sarcocystis neurona infections in raccoons (Procyon lotor): Evidence for natural infection with sarcocysts, transmission of infection to opossums (Didelphis virginiana), and experimental induction of neurologic disease in raccoons. Veterinary Parasitology 100: 117-119.

Fenger, C. K., D. E. Granstrom, A. A. Gajadhar, N. M. Williams, S. A. McCrillis, S. Stamper, J. L. Langemeier, and J. P. Dubey. 1997. Experimental induction of equine protozoal myeloencephalitis in horses using Sarcocystis sp. sporocysts from the opossum (Didelphis virginiana). Veterinary Parasitology 68: 199-213.

LindSAY, D. S., AND J. P. DubEY. 2001. Direct agglutination test for the detection of antibodies to Sarcocystis neurona in experimentally infected animals. Veterinary Parasitology 95: 179-186.

Saville, W. J. A., R. W. Stich, S. M. Reed, C. J. Nuoku, M. J. Oglesbee, A. Wunschmann, D. L. Grover, A. L. Larew-Naugle, J. F. Stanek, D. E. Granstrom, and J. P. Dubey. 2001. Utilization of stress in the development of an equine model for equine protozoal myeloencephalitis. Veterinary Parasitology 95: 211-222. 